\title{
Goat production system at Mymensingh district in Bangladesh
}

\author{
A Kumar ${ }^{1}$, BJ Chae ${ }^{2}$, AKFH Bhuiyan ${ }^{3}$, SC Sarker ${ }^{4}$ and MM Hossain ${ }^{1 *}$ \\ ${ }^{1}$ Department of Animal Science, Bangladesh Agricultural University, Mynensingh-2202, Bangladesh; ${ }^{2}$ College of \\ Animal Life Sciences, Kangwon National University, Chuncheon 200-701, Republic of Korea; ${ }^{3}$ Department of \\ Animal Breeding and Genetics, Bangladesh Agricultural University, Mynensingh-2202, Bangladesh; \\ ${ }^{4}$ Department of Agricultural Economics, Bangladesh Agricultural University, Mynensingh-2202, Bangladesh
}

\begin{abstract}
The experiment was conducted to investigate the present status and potentialities of organic goat production in Mymensingh district of Bangladesh through field survey. The data were collected through an interview schedule personally from 45 respondents in 3 villages of Bhaluka upazila who were involved in goat production. Parameters studied were check list for organic goat production likes origin, feeds and fodder, breeding, health care, living conditions and record keeping of livestock and factors related to organic goat production. In this study, about $100 \%$ goats were indigenous in origin. Among the farmers, $96 \%$ farmers used roadside grass and tree leaves whereas, only $4 \%$ farmers used cultivated fodder which was cultivated in their own land. $85 \%$ farmers used mixed feed which prepared by themselves. However, only $11 \%$ farmers used vitamin mineral supplementation.100\% farmers used natural breeding method for goat breeding. About 91,80 and $100 \%$ farmers practiced vaccination, deworming and castration method, respectively. About $84 \%$ farmers did not use hormone, antibiotic and growth promoter and $67 \%$ farmers removed sick or injured animals from healthy stock. About $100 \%$ farmers allowed access to outdoor and fallow land throughout the year. Only $31 \%$ farmers reared male and female goat separately and $60 \%$ farmers kept livestock record. In Bangladesh goat are reared in the conventional method where different inorganic substances are used by the farmers There are great potentialities for organic goat production in Bangladesh both for satisfying animal protein requirements and production of quality goat meat. For this, it is a prime importance to find out the present status and explore the potentialities of organic goat production in Bangladesh.
\end{abstract}

Key words: goat production, organic, feed additives, antibiotic, growth promoter

Bangladesh Animal Husbandry Association. All rights reserved.

Bang. J. Anim. Sci. 2018. 47 (1):13-20

\section{Introduction}

Livestock is an integral component of agriculture and make multifaceted contributions to the growth and development of the agricultural sectors of Bangladesh. The livestock resources of Bangladesh are mainly based on cattle, goat, sheep, buffalo, and poultry. About 21.6 million (FAO, 2010; BER, 2012) and 25.7 million (BBS, May 2016) goat heads are distributed throughout the country. Although the growth of livestock production is the second highest among all other sub-sector of agriculture in Bangladesh (BER, 2012), the production and consumption of livestock products are still much lower in consumption with other countries. The increasing trends of meat consumption have already been evident in several Southeast Asian countries such as Indonesia, Malaysia, Philippines and Thailand (Skunmun et al., 2002).
According to the report, the requirement of animal protein per head per day is $120 \mathrm{gm}$. However, the availability is only $22.0 \mathrm{gm}$. (DLS, 2011) and the deficit of meat are more than $80 \%$ in 2010 . To satisfy the animal protein requirement, goat farming can play an important role without religious obstacles to consume goat meat. Organic goat production is a means of goat production with a large number of rules directed towards a high status of animal welfare, care for the environment, restricted use of medical drugs and the production of a healthy product without residues (pesticides or medical drugs). Organic livestock production is productive and sustainable (Reganold et al., 1993; Letourneau and Goldstein, 2001; Mader et al., 2002). The organic standards generally prohibit products of genetic engineering and animal cloning, synthetic pesticides, synthetic fertilizers, sewage sludge, synthetic drugs, synthetic food processing aids and ingredients, and ionizing radiation. Prohibited products and

*Corresponding author: mmh_bau2009@yahoo.com 
practices must not be used on certified organic farms for at least three years prior to harvest of the certified organic products (Gerold et al., 2007). Livestock must be raised organically and fed $100 \%$ organic feed ingredients.

In Mymensingh district large numbers of goat are found. Most of the goat farmers are women and they are very poor. Many of them used inorganic substances; growth promoting steroids and feed additives for goat production, but in organic goat production use of these substances is prohibited. The information related to organic goat production by the farmers in Bangladesh is very limited. Detailed study is needed in a different district of Bangladesh to know the present status and recommended organic goat production program for the farmers as an income generating activities and women empowerment. There is a great potentiality of organic goat production in Bangladesh both for satisfying animal protein requirements and production of quality goat meat. Therefore, the present study was undertaken to investigate the present status and explore the potentialities of organic goat production.

\section{Materials and Methods}

The study was conducted in three villages namely Gangatia, Borochala and Pachpaiparagao under Habirbari union at Bhaluka upazila in Mymensingh district. Farmers were randomly chosen from each village under Habirbari unionThe data were collected through interview schedule by selecting 45 respondents from three villages (15 farmers from each village) involved in goat production. A structured interview schedule was carefully prepared keeping the objectives of the study in mind. The questions and statement contained in the schedule were simple, direct and easily understandable by the respondents. Data were collected from respondents in one-to-one interview method. To collect the necessary information from the respondents in both interviewing and observation was applied. The interview schedule contained the following informations; A) Checklist for organic goat production: Origin of livestock, Livestock feed, Livestock breeding, Health care, Living conditions, Record keeping (Chander et al., 2011). B) Socio-economic factors related to organic goat production: Gender, Age of the farmers, Education level, Household size, Occupation, Land size, Training, Source of capital, Number of goats, Description of the goat like breed, age, sex, weight, Purchase time, Goat rearing until marketing/ slaughter. C) Problems and suggestions to improve organic goat production. At the end of data collection, the collected data were coded, compiled, tabulated and analyzed. The local units were converted into standard units. The qualitative data were transferred into quantitative data by appropriate scoring technique. Tabular technique was applied for the analysis of data using simple statistical tools like frequency, average and percentages through SPSS software.

\section{Results and Discussion}

\section{A) Checklist for organic goat production}

\section{Origin of goat}

Table 1 showed that all of the farmers used indigenous (100\%) goat mainly Black Bengal goat (BBG) breed and few of them used Jamunapari breed for goat production in the study area. Most of the farmers (64\%) used own source of goat for goat production. The parameter of origin of goat about $100 \%$ indigenous goats is considered to be organic. Hossain et al., (2016) stated that only $12 \%$ indigenous cattle used for beef cattle production at Shahjadpur upazila in Sirajgong district whereas, Sarker (2014) stated that $100 \%$ indigenous sheep used for sheep production at Ramgoti upazila in Lakshmipur district.

\section{Livestock breeding}

Table 1 showed that $100 \%$ of the farmers used natural breeding for goat production. In organic goat production, reproduction technique should be natural. Artificial insemination is allowed only upon veterinary necessity. Hossain et al., (2016) stated that 73, 13 and $14 \%$ used A.I., natural and both breeding techniques for cattle fattening respectively. Sarker (2014) stated that $100 \%$ of the farmers used natural breeding for sheep production.

\section{Livestock feeds and fodder}

Table 2 showed that most of the farmers (49\%) used both roadside grass and tree leaves, whereas 29, 18 and $4 \%$ farmers used roadside grass, tree leaves and cultivated fodder respectively. Different concentrates feed like wheat bran, rice polish/bran, kheshari bran, till oil cake, mustard oil cake, broken rice, salt etc. used for goat production. Feed additives, hormones, and growth promoter are not mixed with these concentrate ingredients which are prohibited in organic goat production. 
Kumar et al. (2018) Bang. J. Anim. Sci. 47 (1):13-20

Table 1. Origin, source and breeding techniques of goat

\begin{tabular}{llrr}
\hline \multicolumn{1}{c}{ Parameter } & \multicolumn{1}{c}{ Categories } & Number of respondents & Percent of total respondents \\
\hline \multirow{2}{*}{ Origin of goat } & Indigenous & 45 & 100 \\
& Crossbred & 0 & 0 \\
Source of goat & Own source & 29 & 64 \\
& Purchase & 16 & 36 \\
Breeding & Natural & 45 & 100 \\
method & A.I. & 0 & 0 \\
& Natural and A.I. & 0 & 0 \\
\hline
\end{tabular}

Table 2. Goat feeds and fodders (Total respondents, 45)

\begin{tabular}{llcc}
\hline \multicolumn{1}{c}{ Parameter } & \multicolumn{1}{c}{ Categories } & $\begin{array}{c}\text { Number of } \\
\text { respondents }\end{array}$ & $\begin{array}{c}\text { Percent of total } \\
\text { respondents }\end{array}$ \\
& Roadside grass & 13 & 29 \\
Roughage & Cultivated fodder & 2 & 4 \\
& Tree leaves & 8 & 18 \\
Concentrate & Tree leaves \& Roadside grass & 22 & 49 \\
& Compound feed/pellet & 00 & 00 \\
Vitamin, mineral & Mixed feed & 35 & 78 \\
supplement & No & 10 & 22 \\
Feed additives \& growth & Yes & 05 & 11 \\
promoter & No & 40 & 89 \\
Source of concentrate & No & 00 & 00 \\
feed & Produce themselves & 45 & 100 \\
Fertilizer use & Buy locally & 39 & 85 \\
& Yes & 06 & 15 \\
\hline & No & 02 & 04 \\
\hline & & 43 & 96 \\
\hline
\end{tabular}

About $89 \%$ farmers did not use vitamin mineral supplement in feed for goat production. In organic goat farming producers are required to feed livestock, agricultural feed products that are $100 \%$ organic. About $78 \%$ farmers used own prepared mixed feed where feed additive, hormones and growth promoter are not mixed with feed ingredients which meet the organic standard of goat production and the rest of $22 \%$ farmers may not use concentrate feed.

\section{Livestock health care}

Table 3 showed that about $91 \%$ farmers vaccinate their goat regularly. Most of the farmers ( $84 \%$ ) did not use hormones, antibiotic and growth promoter for higher meat production. About $67 \%$ farmers removed their sick animals from healthy stock and $80 \%$ practiced deworming. About $100 \%$ farmers practiced castration in case of buck for goat production. Organically raised animals should not be given hormones to promote growth, or antibiotics for any reason. Animals treated with a prohibited medication would be removed from an organic operation (IFOAM, 2008; FiBLIFOAM-Survey, 2014). The results of this study are similar to (Begum et al., 2007) where they reported that $83.3 \%$ farmers used vaccination, $80 \%$ farmers practiced deworming and $45 \%$ farmers removed sick animals from healthy animals. According to organic livestock production guidelines Chander et al., (2011) 
reported that $91 \%, 84 \%$ and $67 \%$ goats are considered to be organic on the basis of vaccination, antibiotic use and medication.

\section{Livestock living condition}

Table 3 showed that about $100 \%$ farmers allowed animal's access to outdoor and pasture land. Most of the farmers clean housing pens, equipment and utensils regularly. About $78 \%$ farmers use existing traditional goat shed and $22 \%$ farmers use shed for keeping a flock. Only $31 \%$ farmers separated male and female animals and $69 \%$ farmers kept male and female animals together. All organically raised animals must have access to the outdoors, including access to pasture. They may be temporarily confined only for reasons of health safety, the animal's stage of production, or to protect soil or water quality (Chander et al., 2011). In the study area, most of the farmers reared their goat in the existing traditional goat shed and most of the farmers allowed animal access to outdoor and pasture. It is revealed that, it completely fulfilled the organic criteria of animal access to outdoor and pasture.

\section{Record keeping}

Organic production generally requires more record keeping than conventional production. Table 3 showed that most of the farmers (60\%) kept their livestock record and $40 \%$ farmers do not keep their records. However, farmers mostly kept birth record, breeding record, feed record, health record etc. for goat production whereas, Sarker (2014) and Hossain et al., (2016), reported that only 3\% farmers kept their animal records regularly.

\section{B) Socio-economic factors related to organic goat production}

Table 4 shows the socio-economic factors related to organic goat production Data were collected from 45 respondents about their socio-economic condition related to goat production which, including age of the farmers, family size, education, occupation, land size, training and source of capital, purchase time of goat and the duration of the program. Table 4 indicates that the highest proportion (49\%) of the farmers in the study were in the middle aged category whereas, $31 \%$ belonging to young aged and $20 \%$ to old aged category. The results of this study are similar with Rahman et al., (2012), where they reported that $45.3 \%$ farmers were in the middle aged category, 16 and $38.7 \%$ farmers were in young and old age category, respectively.
Table 3. Goat health care, living conditions and record keeping by farmers (Total respondents, 45)

\begin{tabular}{lc}
\hline \multicolumn{1}{c}{ Parameter } & $\begin{array}{c}\text { Percent of } \\
\text { respondents } \\
\text { practiced }\end{array}$ \\
\hline Vaccination & 91 \\
$\begin{array}{l}\text { Hormone, antibiotic } \\
\text { and growth promoter }\end{array}$ & 16 \\
Removal of sick & 67 \\
animals & \\
Deworming & 80 \\
Surgical practice & 100 \\
(castration) & 100 \\
Access to outdoor & 100 \\
Access to pasture & 31 \\
Separate male and \\
female cattle
\end{tabular}

Almost similar findings were found in Sharmin (2005), Begum et al., (2007), Ahamed et al., (2010), Sarker (2014), Hossain et al., (2016) The results of this study were similar with Rahman et al., (2012), where they reported that $44 \%$ farmers had small sized, $38 \%$ medium sized and 18 farmers large sized family. The average family size 5.60 of the respondents in the study area was higher than that of the national average of 4.9 (BBS, 2008). Table 4 shows that, the major category (53\%) of the farmers belongs to a marginal class which was also a representative of the typical land size of Bangladesh. About 29\% farmers small, $13 \%$ medium and $5 \%$ farmers had large size land and the mean was 1.26 acres. Among the total respondents, $11 \%$ illiterate (only signature), $58 \%$ had primary, $22 \%$ had secondary and $09 \%$ had higher secondary level of education (Table 4). The results of this study are similar with (Begum et al., 2007), where they reported that $20.0 \%$ farmer's illiterate, $40.0 \%, 30.0 \%$ and $10.0 \%$ farmers in primary, secondary and above the secondary level of education, respectively. In Table 4, Out of 45 respondents, $51 \%$ are involved in agriculture, $18 \%$ in business and $2 \%$ of government job and $27 \%$ in other jobs, respectively. The results of this study are similar with Sarker (2014), where they reported that $50 \%$ farmers involved in agriculture and $23 \%$ in business and $23 \%$ in another job. Almost similar findings were found by Ahamed et al., (2010). 
Kumar et al. (2018) Bang. J. Anim. Sci. 47 (1):13-20

Table 4. Socio-economic factors related to organic goat production (Total respondents $=45$ )

\begin{tabular}{|c|c|c|c|}
\hline Parameter & Categories & $\begin{array}{l}\text { Number of } \\
\text { respondents }\end{array}$ & $\begin{array}{l}\text { Percent of total } \\
\text { respondents }\end{array}$ \\
\hline \multirow{3}{*}{ Age } & Young age (up to 30 years) & 14 & 31 \\
\hline & Middle age ( $31-50$ years) & 22 & 49 \\
\hline & Old age (above 50 years) & 09 & 20 \\
\hline \multirow[t]{5}{*}{ Household size } & Small family (up to 5 members) & 20 & 44 \\
\hline & Medium family (6-8 members) & 17 & 38 \\
\hline & Large family (above 8 members) & 08 & 18 \\
\hline & Marginal (up to 1 acre) & 24 & 53 \\
\hline & Small (1-3 acre) & 13 & 29 \\
\hline \multirow{4}{*}{ Land size } & Medium (above 3-8 acre) & 06 & 13 \\
\hline & Large (above 9 acres) & 02 & 05 \\
\hline & Illiterate & 05 & 11 \\
\hline & Primary & 26 & 58 \\
\hline \multirow[t]{5}{*}{ Level of education } & SSC & 10 & 22 \\
\hline & HSC & 04 & 09 \\
\hline & Graduate & 00 & 00 \\
\hline & Agriculture & 23 & 51 \\
\hline & Business & 08 & 18 \\
\hline \multirow{2}{*}{ Occupation } & Govt. job & 02 & 04 \\
\hline & Other job & 12 & 27 \\
\hline \multirow[t]{5}{*}{ Source of capital } & Own capital & 28 & 62 \\
\hline & Bank loan & 01 & 02 \\
\hline & NGO loan & 13 & 29 \\
\hline & Lending & 03 & 07 \\
\hline & Have & 30 & 67 \\
\hline \multirow[t]{2}{*}{ Training } & Have not & 15 & 33 \\
\hline & Black Bengal Goat (Deshi) & 45 & 100 \\
\hline \multirow[t]{2}{*}{ Breed type } & Crossbred & 00 & 00 \\
\hline & Around the year & 11 & 25 \\
\hline \multirow[t]{3}{*}{ Purchase time } & Occasionally & 05 & 11 \\
\hline & Not purchase & 29 & 64 \\
\hline & Less than 2 years & 16 & 36 \\
\hline \multirow{2}{*}{$\begin{array}{l}\text { Goat rearing until } \\
\text { marketing }\end{array}$} & $2-3$ years & 11 & 24 \\
\hline & More than 3 years & 18 & 40 \\
\hline
\end{tabular}


Table 5. Present status of organic and conventional goat production (Total respondents $=45$ )

\begin{tabular}{|c|c|c|c|}
\hline $\begin{array}{l}\text { Checklist of organic } \\
\text { goat production }\end{array}$ & Criteria & $\begin{array}{l}\text { Organic } \\
\qquad(\%) \\
(n=45)\end{array}$ & $\begin{array}{l}\text { Conventional (\%) } \\
\qquad(\mathrm{n}=\mathbf{4 5})\end{array}$ \\
\hline \multirow[t]{2}{*}{ Breed } & Indigenous/Crossbred & 100 & 00 \\
\hline & Roughage & 96 & 04 \\
\hline \multirow[t]{2}{*}{ Feed } & Concentrate & Not known & Not known \\
\hline & Vitamin and mineral & 89 & 11 \\
\hline \multirow[t]{2}{*}{ Breeding } & Natural & 100 & 00 \\
\hline & Vaccination & 91 & 09 \\
\hline \multirow[t]{2}{*}{ Health care } & $\begin{array}{l}\text { Antibiotic \& growth } \\
\text { promoter }\end{array}$ & 84 & 16 \\
\hline & Removal of sick animal & 67 & 33 \\
\hline \multirow[t]{2}{*}{ Living conditions } & Access to outdoor & 100 & 00 \\
\hline & Access to pasture & 100 & 00 \\
\hline Record keeping & Kept/Not kept & 60 & 40 \\
\hline
\end{tabular}

Table 4 showed that at $62 \%$ of respondents used own capital for goat production, $2 \%$ respondents taking bank loan and $29 \%$ from other sources such as NGO loan and $7 \%$ lending for goat production. The results of this study are similar with (Sarker, 2014) where he reported that $57 \%$ used own capital, $10 \%$ used bank loan and $33 \%$ from other sources such as NGO loan and lending for goat production.

Table 4 shows that, majority of the respondents had short training on goat production. About $100 \%$ farmers reared native breed (Deshi) and mostly (64\%) farmers reaing goat from their own source whereas, 36\% farmers purchased goat occasionally or around the year for goat production. While working with farmers in rural areas of Bangladesh, almost similar results were found by Rahman et al., (2012) and Hossain et al., (2016).The results of this study differed from Rahman et al., (2012) because most of the farmers at Bhaluka upazila in Mymensingh district used own source of goat for goat production. Table 4 shows that, $36 \%$ farmers reared goats of less than 2 years, $24 \%$ reared goats of $2-3$ years and 40 reared goats of more than 3 years. Most of the farmers reared male goat 2 to 3 years, but in case of female goat they reared 4 to 6 years is depending on production performances, health and family condition of the farmers.

\section{Present status of organic goat production}

In the parameter of breed $100 \%$ goats are considered organic. In case of roughage $96 \%$ of the roughage are organic because most of the farmers use roadside grass and tree leaves were no use of inorganic fertilizer. About $89 \%$ goats are organic criteria of providing vitamin mineral supplement. In the parameter of livestock breeding about $100 \%$ goats are considered to be organic. In the criteria of vaccination about $91 \%$ and removal of sick animal about $67 \%$ goats are organic.

In organic goat production hormone, antibiotic and growth promoter is prohibited, but $16 \%$ farmers use a growth promoter for goat production so, $84 \%$ goats are considered organic. In the parameter of livestock living condition and record keeping about 100 and $60 \%$ goats are organic respectively (Table 5 ). 
Kumar et al. (2018) Bang. J. Anim. Sci. 47 (1):13-20

Table 6. Problems and suggestions to improve organic goat production (Total respondents, 45 )

\begin{tabular}{lcc}
\hline \multicolumn{1}{c}{ Problems and suggestions of organic goat production } & \\
\hline \multicolumn{1}{c}{ Problems } & $\begin{array}{c}\text { Number of } \\
\text { respondents }\end{array}$ & $\begin{array}{c}\text { Percent of total } \\
\text { respondents }\end{array}$ \\
Diseases of goat \& dog biting & 37 & 82 \\
Unavailability of goat feed & 35 & 78 \\
High feed cost & 30 & 67 \\
Lack of land for forage cultivation & 26 & 58 \\
Lack of pasture land & 26 & 58 \\
Lack of motivation \& awareness of the farmers & 25 & 56 \\
Complexity of NGO \& bank loan & 25 & 56 \\
Lack of training facilities & 15 & 33 \\
Marketing \&transportation problem & 10 & 22 \\
\hline \multicolumn{1}{c}{ Suggestions } & & \\
Goat feed should be available \& reduce feed cost & 30 & 67 \\
Pasture land should be available & 10 & 58 \\
Motivation \& create awareness of the farmers & 26 & 22 \\
Vaccine \& medicine should be available & 25 & 56 \\
Easy NGO \& bank loan & 25 & 56 \\
Providing training facilities & 25 & 56 \\
Organic fertilizer should be available & 15 & 33 \\
Improve marketing \& transportation system & 10 & 22 \\
\hline
\end{tabular}

\section{C) Problems faced by the farmers and their expectations}

Table 6 showed problems and suggestions to improve organic goat production. About $78 \%$ farmers reported unavailability of goat feed, $67 \%$ reported high cost of feed and vitamin mineral supplementation, $82 \%$ reported diseases of goat and dog biting, $56 \%$ reported lack of motivation and awareness of the farmers, 51 and $33 \%$ reported lack of technical knowledge and training facilities, $58 \%$ farmers reported lack of pasture land and land for fodder cultivation, $22 \%$ reported marketing and transportation problem, $56 \%$ farmers reported complexity of bank and NGO loan are the major problems in organic goat production. The farmers should be required more motivation, adequate training facilities, goat feed should be available and reduced feed cost, pasture land should be available, easier bank and NGO loan where the most important suggestions by 56 , $33,67,58$ and $56 \%$ of the respondents respectively.
Ali and Anwar (1987) and Hossain et al., (2016), found that high feed cost and shortage of animal feed were the greatest problems of the farmers for rearing cattle. Sarker (2014), reported that unavailability and high cost of feed, lack of training facilities, disorganized marketing system and motivation of the farmers were the problems for goat rearing.

\section{Conclusion}

It can be concluded that the present status of organic goat production in Bangladesh is not satisfactory. Feeds and fodder, health care, record keeping and the extent of knowledge of the respondents of organic goat production was not satisfactory. For wider dissemination of organic goat production technology to the farmers, it is recommended that the concerned authority should take awareness campaign and capacity building of the farmers towards practicing organic goat farming to produce safe food for consumers, for animal welfare while minimizing environmental decay, improving socio-economic conditions of rural masses and also for enhancing women empowerment. 


\section{References}

Ahamed T, MA Hashem, M Khan, MF Rahman and MM Hossain (2010). Factors related to small scale cattle fattening in rural areas of Bangladesh. Bangladesh Journal of Animal Science 39(1-2): 116-124.

Ali MA and ABMN Anwar (1987). Cattle problem confrontation in a union of Mymensingh. Bangladesh Journal of Extension Education 2(1):41-49.

BBS (Bangladesh Bureau of Statistics) (2008). Preliminary Report of Agricultural Census, Bangladesh Bureau of Statistics, Ministry of Planning, Government of the People's Republic of Bangladesh.

BBS (Bangladesh Bureau of Statistics) (May, 2016). Preliminary Report of Agricultural Census, Bangladesh Bureau of Statistics, Ministry of Planning, Government of the People's Republic of Bangladesh.

Begum MAA, MM Hossain, M Khan, MM Rahman MM and SME Rahman (2007). Cattle fattening practices of selected farmers in Panchagarh district. Bangladesh Journal of Animal Science 36(1-2):62-72.

BER (Bangladesh Economic Review) (2012). Ministry of Planning, Government of the People's Republic of Bangladesh.

Chander M, B Subrahmanyeswari, R Mukherjee and S Kumar (2011). Organic livestock production: an emerging opportunity with new challenges for producers in tropical countries. Review Scientifique et Tecnique (International Office of Epizootics) 30 (3):969-983.

DLS (Directorate of Livestock Services) (2011). General information related to livestock. Monthly Fisheries and Livestock Bulletin, published by Fisheries and Livestock Information Office, Khamarbari, Farmgate, Dhaka, Bangladesh.

FAO (2010). Selected indicators of Food and Agriculture Development in Asia pacific region, 1993-2003. Food and Agriculture Organization of the United Nations, Bangkok, Thailand, pp. 119-121.

FiBL-IFOAM-Survey (2014). The World of Organic Agriculture Statistics and Emerging trends.
Hossain MD, MM Hossain, MA Hashem and $\mathrm{KJ}$ Bhuiyan (2016). Organic beef cattle production pattern at Shahjadpur upazilla of Sirajgonj district in Bangladesh. Bangladesh Journal of Animal Science 45(1):25-30.

IFOAM (2008). The World of Organic Agriculture Statistics and emerging trends (Helga Willer and Minou Yussefi Eds.), p. 13-102.

Letourneau DK and B Goldstein (2001). Pest damage and arthropod community structure in organic vs. conventional animal production in California. Journal of Applied Ecology 38(3):557-570.

Mader P, A Fliefback, D Dubois, L Gunst, P Fried and $U$ Niggili (2002). Soil fertility and biodiversity in organic farming Science 296 (5573): 1694-1697.

Rahman Z, Hossain MM and MA Hashem (2012). Cattle fattening program in Dinajpur district of Bangladesh. Progressive Agriculture 23(12):1-13.

Rahmann G and P Sommerakademie (2007). Organic sheep and goat farming: Director of the Germen Research Institute of Organic Farming, Trenthorst.

Reganold JP, AS Palmer, JC Lockhart and AN Macgregor (1993). Soil quality and financial performance of biodynamic and conventional farms in New Zealand. Journal of Soil Science 260 (5106):344-349.

Sarker AK (2014). Present Status of Organic Sheep Production at Ramgoti Upazila in Lakshmipur District. MS Thesis, Department of Animal Science, Faculty of Animal Husbandry, Bangladesh Agricultural University, Mymensingh.

Sharmin H (2005). Rural women's participation of benefits of involvement in income generating activities under non-government organization. An unpublished M S Thesis, Department of Agricultural Extension Education, Bangladesh Agricultural University, Mynensingh, Bangladesh.

Skunmun P, C Chantalakhana, R Pungchai, T Poondusit and P Prucsasrit (2002). Comparative Feeding of Nale Dairy, Beef Cattle and Swamp Buffalo. 1. Economics of Beef Production. Asian-Australian Journal of Animal Science 15 (6):878-883. 